\title{
Study of the Social Acceptance and Self-Esteem Levels of High School Students Who Do Sports towards Disabled Students
}

\section{Estudio de los niveles de aceptación social y autoestima de estudiantes de secundaria que practican deporte hacia estudiantes discapacitados}

\section{İbrahim Dalbudak}

Atabey Vocational School, Isparta University of Applied Sciences, ORCID ID: https://orcid.org/ 0000-0003-2380-803X

\section{Öznur Yaşar(i)}

Faculty of Science, Sociology, University of Namık Kemal, ORCID ID: https://orcid.org/ 0000-0001-9747-973X 


\section{Summary}

Education is everyone's right. This right has been emphasized in many national and international legal texts. Based on this fact, it is extremely important to consider the fact that disabled individuals also have equal rights arising from citizenship as a social acceptance and self-esteem principle. In this sense, social acceptance and self-esteem levels of students who fulfill the special aims of education and do sports towards the students with disabilities emerge as an important issue. Therefore, the aim of this study is to examine the possible relationship between social acceptance and self-esteem levels of different high school students who do sports towards the students with disabilities in Turkey. In this study including high school students doing sports, Social Acceptance Scale and Coopersmith Self-Esteem Inventory were used to evaluate various variables of students towards disabled students. "Mann Whitney U" and "Kruskal Wallis 1 Way ANOVA" tests were used in the analysis of the scores obtained from the research scales of the students. Also, social anxiety results were determined by using the "Dunn's Nonparametric Comparison" test for significant differences. Kolmogorov-Smirnov (KS) and Shapiro-Wilk (SW) tests were used to examine the Coopersmith self-esteem inventory and its sub-dimensions. There is no statistically significant difference between the total score averages of the social acceptance and subscales of the students according to their age, gender, number of siblings, father and mother's education $(\mathrm{p}>.05)$. Social acceptance scale total score averages of students differ according to sports branches $(\mathrm{p}<.05)$. Students' Coopersmith self-esteem inventory and subscale total mean scores do not differ according to age, gender, number of siblings, income levels of their families, and educational status of the mother and father $(p>.05)$. Students' Coopersmith self-esteem inventory and subscale total scores differ according to sports branches $(\mathrm{p}<.05)$. There is no statistically significant relationship between students' "social acceptance scale" and "coopersmith self-esteem inventory" ( $p>.05)$. According to the data obtained from this study, we can say that sports affect the emotions and thoughts of the students, and this has a positive attitude towards disabled students in the classroom. Sport enables individuals to socialize. Regardless of the type of disability, we can say that every individual is valuable for athletes. Sport is brotherhood. Students who play sports can empathize. By directing our students to sports branches according to their abilities, we can change their feelings and thoughts towards disabled people and as a society, we can be more sensitive to disabled people.

Keywords: High School Student, Sports, Disabled, Social Acceptance, Self-esteem.

\section{Resumen}

La educación es un derecho de todos. Este derecho ha sido enfatizado en muchos textos legales nacionales e internacionales. Con base en este hecho, es de suma importancia considerar el hecho de que las personas con discapacidad también tienen iguales derechos derivados de la ciudadanía como principio de aceptación social y autoestima. En este sentido, los niveles de aceptación social y autoestima de los estudiantes que cumplen con los fines especiales de la educación y hacen deporte hacia los estudiantes con discapacidad emergen como un tema importante. Por lo tanto, el objetivo de este estudio es examinar la posible relación entre la aceptación social y los niveles de autoestima de diferentes estudiantes de secundaria que practican deportes con los estudiantes con discapacidad en Turquía. En este estudio, que incluyó a estudiantes de secundaria que practican deportes, se utilizó la Escala de Aceptación Social y el Inventario de Autoestima de Coopersmith para evaluar diversas variables de los estudiantes hacia los estudiantes discapacitados. Las pruebas "Mann Whitney U” y "Kruskal Wallis 1 Way ANOVA" se utilizaron en el análisis de las puntuaciones obtenidas de las escalas de investigación de los estudiantes. Además, los resultados de ansiedad social se determinaron mediante la prueba de "Comparación no paramétrica de Dunn" para detectar diferencias significativas. Se utilizaron las pruebas de Kolmogorov-Smirnov (KS) y Shapiro-Wilk (SW) para examinar el inventario de autoestima de Coopersmith y sus subdimensiones. No existe diferencia estadísticamente significativa entre los promedios de puntajes totales de aceptación social y subescalas de los estudiantes según su edad, género, número de hermanos, educación del padre y de la madre ( $\mathrm{p}>$.05). Los promedios de la 
puntuación total de la escala de aceptación social de los estudiantes difieren según las ramas deportivas ( $\mathrm{p}<.05)$. El inventario de autoestima de Coopersmith de los estudiantes y las puntuaciones medias totales de la subescala no difieren según la edad, el sexo, el número de hermanos, los niveles de ingresos de sus familias y el nivel educativo de la madre y el padre ( $\mathrm{p}$ > .05). El inventario de autoestima de Coopersmith de los estudiantes y los puntajes totales de la subescala difieren según las ramas deportivas $(\mathrm{p}<.05)$. No existe una relación estadísticamente significativa entre la "escala de aceptación social" de los estudiantes y el "inventario de autoestima de Coopermith" ( $p>.05$ ). Según los datos obtenidos de este estudio, podemos decir que el deporte afecta las emociones y pensamientos de los estudiantes, y esto tiene una actitud positiva hacia los estudiantes discapacitados en el aula. El deporte permite a las personas socializar. Independientemente del tipo de discapacidad, podemos decir que cada individuo es valioso para los deportistas. El deporte es hermandad. Los estudiantes que practican deportes pueden sentir empatía. Al dirigir a nuestros estudiantes a las ramas del deporte de acuerdo con sus capacidades, podemos cambiar sus sentimientos y pensamientos hacia las personas con discapacidad y, como sociedad, podemos ser más sensibles con las personas con discapacidad.

Palabras clave: Estudiante de secundaria, deportes, discapacitados, aceptación social, autoestima.

\section{Introduction}

Education is the process of preparing the growing generations for social life. Younger generations learn the history, culture and values of the society in which they live through education. In this respect, education emerges as a process of transferring culture and values. This reality in education is reinforced by the following quotation: "Children born today will live tomorrow, raise your child for tomorrow" (Doğan, 2018). In this sense, it is necessary to educate young people, who are the adults of tomorrow, to be sensitive about certain issues. Especially, the issue of behaviors of young people who do sports and have a guiding mission to the society in every sense is an important issue.

There are general and specific purposes of the education at school. Teaching new knowledge and skills in the world creates general purposes. General purposes process the human dimension that is open to the world. They aim at the development of human biological, mental and emotional characteristics. Every state in the world makes regulations for its citizens to develop in this direction. The special purposes of education are to teach the unique needs of the society and cultural values. Special purposes create the national dimension of education. Society's expectations and needs are determined via specific purposes. The answer to the question "how to raise people who are beneficial to their country and society" was sought in special purposes. In other words, it is aimed to raise happy people who contribute to the society and humanity, who can establish the balance of body and soul, who are hardworking, productive, and able to establish the balance of body and soul through the special purposes of education (Doğan, 2018). According to this definition, young people who do sports are in the category of young people who strive to achieve the special goals of education. On the other hand, the disabled people form a significant proportion of the world population. Similarly, there are students with mental, visual, physical and hearing disabilities in schools. Because every individual has the right to receive an equal education. Despite this, disabled people face problems in this regard compared to non-disabled individuals. Some attitudes towards disabled people make it difficult for disabled students to integrate into the school. In this sense, the social acceptance and self-esteem level developed by the students who are equipped with the special purposes of education towards the students with disabilities emerge as an important issue. Therefore, the aim of this study is to examine the social acceptance and self-esteem levels of high school students doing sports towards disabled students.

It is emphasized in many national and international legal texts that everyone has the right to get education. In our country, education services are a right for individuals and a duty for the state, which is guaranteed by the statement "no one can be deprived of the right to get education and training" in the forty-second article of our constitution. The right to get education, which is 
guaranteed by national and international laws, is undoubtedly indispensable for all individuals regardless of their religion, language, race, gender, physical condition and mental differences. Based on this fact, it is extremely important to consider the fact that disabled individuals also have equal rights arising from citizenship as a social acceptance principle (Selimoğlu \& Aydın, 2019). Especially young people who do sports are expected to be more sensitive about this issue in the context of the special aims of education. Social acceptance can be defined as an attitude that reflects the collective values of group members' feelings towards individuals such as liking and disliking (Buhs \& Ladd, 2001). All people feel the need for a positive and continuous social relationship. Social acceptance is important for establishing a positive social relationship between people. Leary said that social acceptance has a wide range from tolerating the existence of another to making an effort to communicate with someone (Cited in: DeWall \& Bushman, 2011). Although they differ from their peers in certain areas, social acceptance is also very important in the lives of disabled individuals (B1yıkl1, 1989 cited. Aktaş and Küçüker 2002; Öcal, 1999). For this reason, the environments where they are together with their peers play an extremely important role in the education of the disabled. The concept of social acceptance, which is generally understood as accepting others by an individual, can be a little more complicated in the acceptance of disabled individuals who are disadvantaged when the features mentioned above such as social awareness, friendship and maintaining communication are considered (Karataş \& Arslan, 2018). Therefore, Özyürek (2006) He emphasized the importance of accepting disabled people by nondisabled individuals by defining social acceptance as positive attitudes of the individuals not affected from disability towards individuals affected from disability and seeing them as others.

According to Coopersmith who explains the concept of self-esteem, which is very important personally, socially and psychologically, self-esteem is an individual's evaluation which he/she makes his/her self and continues as a habit. The level of self-esteem determines the individual's attitudes that approve or disapprove of his/her own self and the belief that the individual is talented, important, successful and valuable. In summary, Coopersmith defines selfesteem as an evaluation of the individual's own dignity (Coopersmith, 1974). Rosenberg also emphasized that the self-esteem of the individual has a central importance in psychological sense, giving special importance to the concept of self-esteem. Self-esteem is the result of selfevaluation. The judgment reached by the individual as a result of his/her self-evaluation determines the level of self-esteem. Self-esteem is the valence judgment reached by an individual regarding the self-concept (Rosenberg, 1965). It is expressed with different terms such as selfesteem, self-respect, self-respect (Kuzgun 2000, Coopersmith 1974, Yiğit, Y1lmaz 2011). People with high self-esteem are those who are self-confident, not afraid of criticism, have realistic goals, strive for these goals, are active and sociable, have a high acceptance level, are successful academically and socially, and have a positive perception of themselves. People with low selfesteem are those who seek approval, have fears, are more fragile in the face of criticism, are dependent, cannot act like themselves when the need for approval is high, do not take risks, set modest goals, and are full of their own problems (Pişkin, 2000; Mağden \& Aksoy, 1993; Cohen, 1959). In the studies conducted, we can explain that sport has an impact on students because of the high self-esteem levels of individuals who do sports and their positive attitudes towards disabled individuals.

As a result, it is seen that sport has an important place on students because it affects emotions and thoughts. Therefore, this study is an important study in order to determine the attitudes of students who do sports regularly towards disabled students and to determine whether sport has an impact on students' feelings and thoughts. For this reason, in this study, it is aimed to examine the relationship between social acceptance of high school students engaged in sports and their self-esteem levels towards disabled students.

\section{Methodology \\ Research Model}

In this study, descriptive and relational survey methods, which are general survey models, were used. 


\section{Forming Volunteer Groups}

Students who were studying at different high schools in Turkey in the 2019-2020 academic year participated in the study voluntarily.

\section{Data Collection Techniques}

As data collection techniques, Personal Information Form, Social Acceptance Scale and

Coopersmith Self-Esteem Scale were used.

\section{Personal Information Form}

In obtaining the data, the questions prepared by the researcher regarding demographic characteristics and including gender, age, education status of the mother and father, economic status, sports branch, number of siblings were used.

\section{Social Acceptance Scale}

Social acceptance scale developed by Arslan (2010) consists of 32 items. The scale is a triple Likert type scale. The first of the three factors that make up the scale is defined as "Social Skills", the second as "Student Behavior", and the third as "Peer Attitude". The high value obtained from the scale indicates that the students developed a "positive attitude" towards the inclusive students, while the lower value shows that the students developed a "negative attitude". Cronbach Alpha internal consistency coefficient was found as .92 (Karataş \& Aslan, 2018).

\section{Coopersmith Self-Esteem Scale}

Coopersmith Self Esteem Inventory, developed by Stanley Coopersmith (1986) and then revised, consists of 58 items in total. The scale is a 2-point Likert type scale. The scale is a measurement tool with "Yes and No" options. The scale consists of 5 sub-items. The scale consists of items developed to measure an individual's thoughts about himself in his social, academic, family and personal life. According to Güçray (1989), it was first conducted by Onur (1980). Later, the adaptation made by Güçray (1989) was carried out. The last adaptation of the Coopersmith SelfEsteem Inventory into Turkish was made by Pişkin (1996). Reliability coefficient of the Coopersmith Self-Esteem Inventory was found as .70.

\section{DISTRIBUTION OF DEMOGRAPHIC FEATURES}

Table 1. Distribution of the Demographic Characteristics of the Student Participating in the

\begin{tabular}{lll}
\hline Variable & Study & \\
\hline Age & $\begin{array}{l}\text { Frequency } \\
\text { (n) }\end{array}$ & $\begin{array}{l}\text { Percentage } \\
(\%)\end{array}$ \\
15 & & \\
16 & 91 & 22,5 \\
17 & 105 & 26,0 \\
18 & 109 & 27,0 \\
Total & 99 & 24,5 \\
& 404 & 100,0 \\
\hline Gender & & \\
Male & 319 & 79,0 \\
Female & 85 & 21,0 \\
Total & 404 & 100,0 \\
\hline Mother's & & \\
Educational Level & & \\
Primary Education & 30 & 7,4 \\
High School & 126 & 31,2 \\
Undergraduate & 146 & 36,2 \\
Postgraduate & 102 & 25,2 \\
Total & 404 & 100,0 \\
\hline
\end{tabular}




\begin{tabular}{lll}
\hline $\begin{array}{l}\text { Father's Educational } \\
\text { Level }\end{array}$ & & \\
High School & 100 & 24,8 \\
Undergraduate & 217 & 53,7 \\
$\begin{array}{l}\text { Postgraduate } \\
\text { Total }\end{array}$ & 87 & 21,5 \\
& 404 & 100,0 \\
\hline Sport Branch & & \\
Individual Sports & 143 & 35,4 \\
Team sports & 261 & 64,6 \\
Total & 404 & 100,0 \\
\hline $\begin{array}{l}\text { Number of siblings } \\
1\end{array}$ & 102 & 25,2 \\
2 & 215 & 53,3 \\
3 or more & 87 & 21,5 \\
Total & 404 & 100,0 \\
\hline Level of Family & & \\
Income & & \\
2001-4000 TL & 4 & 1,0 \\
4001 - 5000 TL & 86 & 21,3 \\
5001 - 6000 TL & 175 & 43,3 \\
6001 TL and above & 139 & 34,4 \\
Total & 404 & 100,0 \\
\hline
\end{tabular}

The distribution of findings related to the socio-demographic characteristics of the individuals participating in the study is given.

\section{SOCIAL ACCEPTANCE SCALE}

"Social Acceptance Scale" consists of 32 statements. There are three possible options for each question (yes, undecided, no) and the minimum score for each question is 1 and the maximum score is 3. Therefore, the minimum score that can be obtained from the scale is 32 and the maximum score is 96 .

Evaluation for positive statements; (1) no, (2) undecided and (3) yes

Evaluation for negative statements; (1) yes, (2) undecided and (3) no

Negative statements; 4 - 12 - 15 - 17 - 18 - 25 - 29 - 30 - 32

Social acceptance scale consists of 3 subscales;

i. Social skills: 1 - 2 - 8 - 9 - 11 - 16 - 19-21 - 22 - 23 - 24 - 26 - 27 - 28 - 29 - 31

ii. Student behaviors: 3 - 4 - 5 - 6 - $7-10-13-14-20$

iii. Peer attitude: $12-15-17-18-25-30-32$.

\section{Scale Reliability}

The answers given to the scale by a group of 404 students who were applied the "Social Acceptance Scale" has a direct effect on the reliability of the scale. 
Table 2. Cronbach's Alpha Values of "Social Acceptance Scale" and "Subscales"

\begin{tabular}{lc}
\hline Scale and Subscales & $\begin{array}{c}\text { Cronbach's Alpha } \\
\text { Value }\end{array}$ \\
\hline $\begin{array}{l}\text { Social Acceptance } \\
\text { Scale }\end{array}$ & 0,908 \\
\hline Social skills & 0,863
\end{tabular}

\begin{tabular}{|c|c|c|c|}
\hline \multirow{2}{*}{$\begin{array}{l}\text { According to } \\
\text { Alpha value of } \\
\text { group was found } \\
\text { the highly } \\
\text { the subscales of th } \\
(\alpha=0.872) \text { can be }\end{array}$} & Student Behaviors & 0,872 & \multirow{2}{*}{$\begin{array}{l}\text { the table, the Cronbach's } \\
\text { the scale applied to the study } \\
\text { to be } \alpha=0.908 \text {. The scale is in } \\
\text { reliable category. Considering } \\
\text { 863) and "Student Behaviors" } \\
\text { itude" }(\alpha=0.677) \text { subscale can }\end{array}$} \\
\hline & Peer Attitude & 0,677 & \\
\hline
\end{tabular}

\section{Interpreting the Relationship Between "Social Acceptance Scale" and Subscale Total Scores} with Correlation Coefficient

Table 3. Kendall's tau-B Correlation Coefficient Values

\begin{tabular}{lcccc}
\hline & $\begin{array}{c}\text { Social } \\
\text { skills }\end{array}$ & $\begin{array}{c}\text { Student } \\
\text { Behavio } \\
\text { rs }\end{array}$ & $\begin{array}{c}\text { Peer } \\
\text { Attitude }\end{array}$ & $\begin{array}{c}\text { Social } \\
\text { Accepta } \\
\text { nce } \\
\text { Scale }\end{array}$ \\
\hline Social skills & 1,000 & $\begin{array}{c}0,502^{* *} \\
(0,000)\end{array}$ & $\begin{array}{c}0,154^{* *} \\
(0,000)\end{array}$ & $\begin{array}{c}0,442 * * \\
(0,000)\end{array}$ \\
Student & $0,502^{* *}$ & 1,000 & $-0,056$ & $0,479 * *$ \\
Behavior & $(0,000)$ & & $(0,196)$ & $(0,000)$ \\
Peer Attitude & $0,154^{* *}$ & $-0,056$ & 1,000 & $0,444 * *$ \\
& $(0,000)$ & $(0,196)$ & & $(0.000)$ \\
Social & $0,442^{* *}$ & $0,479 * *$ & $0,444 * *$ & 1,000 \\
Acceptance & $(0,000)$ & $(0,000)$ & $(0.000)$ & \\
Scale & & & & \\
\hline
\end{tabular}

* The correlation is significant at the 0.01 level.

When looking at the table, there is no statistically significant relationship between the "student behaviors" levels of the individuals and their "peer attitude" levels. On the other hand, there is a reverse relationship between "social skill" level and "peer attitude" level. As the "peer attitude" levels of individuals decrease, their "social skill" levels increase. There is a statistically significant positive (same) directional relationship between all other subscales and between subscales and social acceptance scale at the level of 0.01 .

ANALYSIS OF TOTAL SCORES OF "SOCIAL ACCEPTANCE SCALE" ACCORDING TO THE DEMOGRAPHIC CHARACTERISTICS OF STUDENTS

In the tables below, summary statistics based on demographic characteristics of the scale total scores, p-values obtained from the "Mann Whitney U" and "Kruskal Wallis 1 Way ANOVA" tests are given. The mean and standard deviation of each subscale are given according to the related grouped variable. In addition, in cases where there is a significant difference, the scales of the differences were determined by using the "Dunn's Nonparametric Comparison" test. 
Table 4. The Results of Social Anxiety Scale towards Disabled Students and Subscales of High School Students Doing Sports by Age

Age

\begin{tabular}{|c|c|c|c|c|c|c|c|c|c|}
\hline & \multicolumn{2}{|c|}{15} & \multicolumn{2}{|c|}{16} & \multicolumn{2}{|c|}{17} & \multicolumn{2}{|c|}{18} & value \\
\hline & $\begin{array}{c}\text { Mea } \\
\mathbf{n}\end{array}$ & SD & $\begin{array}{c}\text { Mea } \\
\mathbf{n}\end{array}$ & SD & $\begin{array}{c}\text { Mea } \\
\text { n }\end{array}$ & SD & Mean & SD & \\
\hline Socialskills & $\begin{array}{c}40,40 \\
66\end{array}$ & $\begin{array}{c}6,202 \\
1\end{array}$ & $\begin{array}{c}40,94 \\
39\end{array}$ & $\begin{array}{c}5,762 \\
3\end{array}$ & $\begin{array}{c}40,48 \\
60\end{array}$ & $\begin{array}{c}5,916 \\
6\end{array}$ & $\begin{array}{c}40,98 \\
99\end{array}$ & $\begin{array}{c}5,357 \\
6\end{array}$ & 0,498 \\
\hline $\begin{array}{l}\text { Student } \\
\text { Behaviors }\end{array}$ & $\begin{array}{c}26,03 \\
30\end{array}$ & $\begin{array}{c}2,778 \\
6\end{array}$ & $\begin{array}{c}25,99 \\
07\end{array}$ & $\begin{array}{c}2,856 \\
6\end{array}$ & $\begin{array}{c}26,18 \\
69\end{array}$ & $\begin{array}{c}2,282 \\
5\end{array}$ & $\begin{array}{c}26,38 \\
38\end{array}$ & $\begin{array}{c}1,833 \\
4\end{array}$ & 0,848 \\
\hline Peer Attitude & $\begin{array}{c}18,02 \\
20\end{array}$ & $\begin{array}{c}2,250 \\
8\end{array}$ & $\begin{array}{c}17,28 \\
97\end{array}$ & $\begin{array}{c}2,426 \\
3\end{array}$ & $\begin{array}{c}17,85 \\
98\end{array}$ & $\begin{array}{c}2,221 \\
0\end{array}$ & $\begin{array}{c}17,91 \\
92\end{array}$ & $\begin{array}{c}2,439 \\
7\end{array}$ & 0,116 \\
\hline $\begin{array}{l}\text { Social } \\
\text { Acceptance } \\
\text { Scale }\end{array}$ & $\begin{array}{c}84,46 \\
15\end{array}$ & $\begin{array}{c}8,894 \\
8\end{array}$ & $\begin{array}{c}84,22 \\
43\end{array}$ & $\begin{array}{c}8,713 \\
8\end{array}$ & $\begin{array}{c}84,53 \\
27\end{array}$ & $\begin{array}{c}8,420 \\
9\end{array}$ & $\begin{array}{c}85,29 \\
29\end{array}$ & $\begin{array}{c}6,998 \\
9\end{array}$ & 0,631 \\
\hline
\end{tabular}

There is no statistically significant difference between the subscales and social acceptance scale total score averages of the students according to their ages. $(p>.05)$.

Table 5. The Results of Social Anxiety Scale towards Disabled Students and Subscales of High School Students Doing Sports by Gender

\begin{tabular}{|c|c|c|c|c|c|}
\hline & \multicolumn{4}{|c|}{ Gender } & \multirow{3}{*}{$\begin{array}{l}\text { p-value } \\
\text { (Sig.) }\end{array}$} \\
\hline & \multicolumn{2}{|c|}{ Male } & \multicolumn{2}{|c|}{ Female } & \\
\hline & Mean & SD & Mean & SD & \\
\hline Social skills & $\begin{array}{c}41,639 \\
5\end{array}$ & 5,5330 & $\begin{array}{c}40,988 \\
2\end{array}$ & 6,7161 & 0,097 \\
\hline $\begin{array}{l}\text { Student } \\
\text { Behaviors }\end{array}$ & $\begin{array}{c}27,253 \\
9\end{array}$ & 2,0607 & $\begin{array}{c}24,752 \\
9\end{array}$ & 3,5920 & $0,000^{*}$ \\
\hline Peer Attitude & $\begin{array}{c}17,705 \\
3 \\
\end{array}$ & 2,3312 & $\begin{array}{c}16,964 \\
7\end{array}$ & 2,4075 & 0,237 \\
\hline $\begin{array}{l}\text { Social } \\
\text { Acceptance } \\
\text { Scale }\end{array}$ & $\begin{array}{c}86,598 \\
7\end{array}$ & 7,8473 & $\begin{array}{c}82,705 \\
9\end{array}$ & 9,7392 & $0,000^{*}$ \\
\hline
\end{tabular}

Individuals" levels of "social skills" and "peer attitude" do not differ according to their gender. (p>.05). However, "student behaviors" subscale total scores and "social acceptance scale" are higher in men than in women. ( $\mathrm{p}<.05)$.

Table 6. The Results of Social Anxiety Scale towards Disabled Students and Subscales of High School Students Doing Sports by Mother's Education Level

\begin{tabular}{|c|c|c|c|c|c|c|c|c|c|}
\hline & & & & & & & & & \\
\hline & \multicolumn{8}{|c|}{ Mother's Education Level } & \multirow{3}{*}{$\begin{array}{c}\text { p- } \\
\text { value } \\
\text { Sig.( }\end{array}$} \\
\hline & \multicolumn{2}{|c|}{ Primary } & \multicolumn{2}{|c|}{ High School } & \multicolumn{2}{|c|}{ Undergraduat } & \multicolumn{2}{|c|}{ Postgraduate } & \\
\hline & Mea & SD & Mea & SD & Mean & SD & Mean & SD & \\
\hline Social skills & 41,20 & 5,665 & 42,00 & 5,738 & 42,22 & 5,0919 & 38,764 & 6,7313 & $0,024 *$ \\
\hline Student & 26,23 & 1,430 & 26,34 & 1,843 & 26,33 & 2,1823 & 25,607 & 3,4986 & 0,086 \\
\hline Peer Attitude & $1 \overline{7,96}$ & $2, \overline{2} 35$ & $1 \overline{7}, \overline{6} 2$ & 2,300 & $1 \overline{7,97}$ & 2,3384 & $17, \overline{5} 49$ & 2,4479 & 0,241 \\
\hline Social & 85,40 & 7,690 & 85,98 & 7,557 & $86 \overline{54}$ & 7,1622 & 81,921 & 10,350 & $0,007 *$ \\
\hline
\end{tabular}


Individuals" "student behavior" and "peer attitude" subscale total scores do not differ according to the education level of their mothers. ( $p>.05)$. However, the total scores of the "social skills" subscale and the "social acceptance scale" of individuals whose mother's education level is graduate is lower than that of individuals whose mother's education level is primary, high school, and undergraduate $(\mathrm{p}<.05)$.

Table 7. The Results of Social Anxiety Scale towards Disabled Students and Subscales of High School Students Doing Sports by Father's Education Level

\begin{tabular}{|c|c|c|c|c|c|c|c|}
\hline & \multicolumn{6}{|c|}{ Father's Education Level } & \multirow[b]{3}{*}{$\begin{array}{l}\text { p- } \\
\text { value } \\
\text { Sig.( }\end{array}$} \\
\hline & \multicolumn{2}{|c|}{ High School } & \multicolumn{2}{|c|}{ Undergraduate } & \multicolumn{2}{|c|}{ Postgraduate } & \\
\hline & Mean & $\begin{array}{c}\text { Std. } \\
\text { Devia } \\
\text { tion }\end{array}$ & Mean & $\begin{array}{c}\text { Std. } \\
\text { Devia } \\
\text { tion }\end{array}$ & Mean & $\begin{array}{c}\text { Std. } \\
\text { Devia } \\
\text { tion }\end{array}$ & \\
\hline Social skills & $\begin{array}{c}40,710 \\
0\end{array}$ & 5,2035 & $\begin{array}{c}40,654 \\
4\end{array}$ & 6,2156 & $\begin{array}{c}40,862 \\
1\end{array}$ & 5,3963 & 0,326 \\
\hline $\begin{array}{l}\text { Student } \\
\text { Behaviors }\end{array}$ & $\begin{array}{c}26,230 \\
0\end{array}$ & 2,4240 & $\begin{array}{c}26,092 \\
2\end{array}$ & 2,5167 & $\begin{array}{c}26,195 \\
4\end{array}$ & 2,4104 & 0,758 \\
\hline Peer Attitude & $\begin{array}{c}17,770 \\
0\end{array}$ & 2,2956 & $\begin{array}{c}17,594 \\
5\end{array}$ & 2,4611 & $\begin{array}{c}18,160 \\
9\end{array}$ & 2,0735 & 0,334 \\
\hline $\begin{array}{l}\text { Social } \\
\text { Acceptance } \\
\text { Scale }\end{array}$ & $\begin{array}{c}84,710 \\
0\end{array}$ & 7,7202 & $\begin{array}{c}84,341 \\
0\end{array}$ & 8,8821 & $\begin{array}{c}85,218 \\
4\end{array}$ & 7,2823 & 0,799 \\
\hline
\end{tabular}

Individuals' 'total scores from the "social acceptance scale" and its subscales do not differ according to their fathers' educational level $(\mathrm{p}>.05)$.

Table 8. The Results of Social Anxiety Scale towards Disabled Students and Subscales of High School Students Doing Sports by the Number of Siblings

\begin{tabular}{|c|c|c|c|c|c|c|c|}
\hline & \multicolumn{6}{|c|}{ Number of siblings } & \multirow{3}{*}{$\begin{array}{c}\text { p- } \\
\text { value } \\
\text { (Sig.) }\end{array}$} \\
\hline & \multicolumn{2}{|c|}{1} & \multicolumn{2}{|c|}{2} & \multicolumn{2}{|c|}{3 and above } & \\
\hline & Mean & SD & Mean & SD & Mean & SD & \\
\hline Social skills & $\begin{array}{c}40,67 \\
65\end{array}$ & 5,8532 & $\begin{array}{c}40,79 \\
53\end{array}$ & 6,0058 & $\begin{array}{c}40,55 \\
17\end{array}$ & 5,2268 & 0,488 \\
\hline Student Behaviors & $\begin{array}{c}26,19 \\
61\end{array}$ & 2,5641 & $\begin{array}{c}26,14 \\
42\end{array}$ & 2,4404 & $\begin{array}{c}26,10 \\
34\end{array}$ & 2,4401 & 0,501 \\
\hline Peer Attitude & $\begin{array}{c}17,87 \\
25 \\
\end{array}$ & 2,4237 & $\begin{array}{c}17,72 \\
09 \\
\end{array}$ & 2,3514 & $\begin{array}{c}17,72 \\
41 \\
\end{array}$ & 2,2654 & 0,783 \\
\hline Social Acceptance Scale & $\begin{array}{c}84,74 \\
51 \\
\end{array}$ & 8,6433 & $\begin{array}{c}84,66 \\
05 \\
\end{array}$ & 8,3856 & $\begin{array}{c}84,37 \\
93 \\
\end{array}$ & 7,5870 & 0,577 \\
\hline
\end{tabular}

There is no statistically significant difference between the subscales of the individuals according to the number of siblings and the total score averages of the social acceptance scale $(p>.05)$.

Table 9. The Results of Social Anxiety Scale towards Disabled Students and Subscales of High School Students Doing Sports by Income Status

\begin{tabular}{|c|c|c|c|c|c|c|c|c|c|}
\hline & \multicolumn{8}{|c|}{ Income status } & \multirow{3}{*}{$\begin{array}{l}\text { p- } \\
\text { value } \\
\text { Sig. }\end{array}$} \\
\hline & \multicolumn{2}{|c|}{$2001-4000$} & \multicolumn{2}{|c|}{$4001-5000$} & \multicolumn{2}{|c|}{$5001-6000$} & \multicolumn{2}{|c|}{6001 TL and } & \\
\hline & Mea & SD & Mea & SD & Mea & SD & Mean & SD & \\
\hline Social skills & 27,7 & 12,23 & 40,3 & 5,833 & 40,80 & 5,811 & 41,21 & 5,101 & 0,004 \\
\hline Student & 14,5 & 5,744 & 26,1 & 2,556 & 26,14 & 2,308 & 26,50 & 1,495 & 0,000 \\
\hline Peer Attitude & 19,0 & 2,708 & 17,6 & 2,495 & 17,69 & 2,281 & 17,87 & 2,336 & 0,465 \\
\hline Social & 61,2 & 15,30 & 84,1 & 8,935 & 84,64 & 8,131 & 85,58 & 6,712 & 0,013 \\
\hline
\end{tabular}


Individuals" "social skills" and "student behavior" subscale total scores and "social acceptance scale" total scores were found to be lower in individuals with an income of 2001 - $4000 \mathrm{TL}$ compared to individuals with higher income $(\mathrm{p}<.05)$. In addition, individuals' "peer attitude" subscale total scores do not differ according to their income levels $(p>.05)$.

Table10. The Results of Social Anxiety Scale towards Disabled Students and Subscales of High School Students Doing Sports by Sports Branch

\begin{tabular}{|c|c|c|c|c|c|}
\hline & \multicolumn{4}{|c|}{ Sport Branch } & \multirow{3}{*}{$\begin{array}{c}\text { p-value } \\
\text { (Sig.) }\end{array}$} \\
\hline & \multicolumn{2}{|c|}{ Individual Sports } & \multicolumn{2}{|c|}{ Team sports } & \\
\hline & Mean & SD & Mean & SD & \\
\hline Social skills & $\begin{array}{c}41,937 \\
1\end{array}$ & 5,4594 & $\begin{array}{c}39,590 \\
0\end{array}$ & 5,9772 & 0,559 \\
\hline $\begin{array}{l}\text { Student } \\
\text { Behaviors }\end{array}$ & $\begin{array}{c}27,335 \\
7\end{array}$ & 2,1261 & $\begin{array}{c}26,046 \\
0\end{array}$ & 2,6322 & 0,381 \\
\hline Peer Attitude & $\begin{array}{c}18,776 \\
2 \\
\end{array}$ & 2,3629 & $\begin{array}{c}17,751 \\
0\end{array}$ & 2,3425 & 0,835 \\
\hline $\begin{array}{l}\text { Social } \\
\text { Acceptance } \\
\text { Scale }\end{array}$ & $\begin{array}{c}88,049 \\
0\end{array}$ & 7,4184 & $\begin{array}{c}83,387 \\
0\end{array}$ & 8,7036 & $0,002 *$ \\
\hline
\end{tabular}

The total scores obtained by individuals from "social skills", "student behavior" and "peer attitude" subscales do not differ according to sports branches ( $p>.05)$. However, the total scores of "social acceptance scale" of individuals dealing with individual sports were higher than those dealing with "team sports" $(\mathrm{p}<.05)$.

\section{COOPERSMITH SELF-Esteem INVENTORY}

\section{General Information}

"Coopersmith self-esteem inventory" consists of 58 statements. There are two options for each statement: Yes or No. The Coopersmith Self-Esteem Inventory consists of 4 subscales;

i. General self-esteem (1 - 3 - 4 - 7 - 10 - 12 - 13 - 15 - 18 - 19 - 24 - 25 - 27 - 30 - 31 - 34 $-35-38-39-43-47-48-51-55-56-57)$

ii. Social self-esteem (5 - 8 - $14-21-28-40-49-52)$

iii. Home-family self-esteem (6 - 9 - $11-16$ - 20 - 22 - 29 - 44)

iv. School-academic self-esteem (2 - $17-23-33-37-42-46-54)$

Fake items not included in the total score (26 - 32 - 36 - 41 - 45 - 50 - 53 - 58)

Scale Reliability

The answers given to the scale by a group of 404 students on the "Coopersmith Self-Esteem Inventory" has a direct effect on the reliability of the scale. 
Table.11 Cronbach's Alpha Values of the "Coopersmith Self-Esteem Inventory" and "Sub-Scales"

\begin{tabular}{lc}
\hline Scale and Subscales & $\begin{array}{c}\text { Cronbach's Alpha } \\
\text { Value }\end{array}$ \\
\hline $\begin{array}{l}\text { Coopersmith Self-Esteem } \\
\text { Inventory }\end{array}$ & 0,913 \\
\hline General Self-Esteem & 0,807 \\
Social Self-Esteem & 0,818 \\
Home-Family Self-Esteem & 0,888 \\
School-Academic Self-Esteem & 0,627 \\
\hline
\end{tabular}

Cronbach's Alpha value of the scale applied to the study group according to the table was found to be $\alpha=0,913$. The scale is in the highly reliable category. Looking at the subscales of the scale, "General self-esteem" $(\alpha=0,807)$ is very reliable, "social self-esteem" $(\alpha=0.618)$ is quite reliable, "home-family self-esteem" $(\alpha=0.888)$ is quite reliable, and "School-Academic Self-Esteem" $(\alpha=0.627)$ subscale can be evaluated in the "acceptable" reliability category.

\section{Interpreting the Relationship Between "Coopersmith Self-Esteem Inventory" and Subscale Total Scores with Correlation Coefficient}

Since the scale and subscale total scores did not conform to the normal distribution, Kendall's tau-B correlation coefficient was used again. In the table below, Kendall's tau-B correlation coefficient values between all subscales and the general scale are given. The value in the cell shows Kendall's tau-B correlation coefficient, and the value in parentheses shows the p-value of whether the relationship is significant or not. The fact that the correlation coefficient between the two variables is not statistically significant indicates that the two related variables are independent from each other.

Table 12. Kendall's tau-B Correlation Coefficient Values

\begin{tabular}{|c|c|c|c|c|c|}
\hline & $\begin{array}{l}\text { General } \\
\text { Self- } \\
\text { Esteem }\end{array}$ & $\begin{array}{l}\text { Social } \\
\text { Self- } \\
\text { Esteem }\end{array}$ & $\begin{array}{l}\text { Home- } \\
\text { Family } \\
\text { Self- } \\
\text { Esteem } \\
\end{array}$ & $\begin{array}{l}\text { School- } \\
\text { Academ } \\
\text { ic Self- } \\
\text { Esteem } \\
\end{array}$ & $\begin{array}{c}\text { Coopers } \\
\text { mith Self- } \\
\text { Esteem } \\
\text { Inventory }\end{array}$ \\
\hline $\begin{array}{l}\text { General Self- } \\
\text { Esteem }\end{array}$ & 1,000 & $\begin{array}{c}0,610 * * \\
(0,000)\end{array}$ & $\begin{array}{c}0,571^{* *} \\
(0,000)\end{array}$ & $\begin{array}{c}0,695^{* *} \\
(0,000)\end{array}$ & $\begin{array}{c}0,844 * * \\
(0,000)\end{array}$ \\
\hline $\begin{array}{l}\text { Social Self- } \\
\text { Esteem }\end{array}$ & $\begin{array}{c}0,610^{* * *} \\
(0,000)\end{array}$ & 1,000 & $\begin{array}{c}0,667 * * \\
(0,000)\end{array}$ & $\begin{array}{c}0,511 * * \\
(0,000)\end{array}$ & $\begin{array}{c}0,760 * * \\
(0,000)\end{array}$ \\
\hline $\begin{array}{l}\text { Home-Family } \\
\text { Self-Esteem }\end{array}$ & $\begin{array}{c}0,571 \text { ** } \\
(0,000)\end{array}$ & $\begin{array}{c}0,667 * * \\
(0,000)\end{array}$ & 1,000 & $\begin{array}{c}0,432 * * \\
(0.000)\end{array}$ & $\begin{array}{c}0,691 * * \\
(0,000)\end{array}$ \\
\hline $\begin{array}{l}\text { School- } \\
\text { Academic } \\
\text { Self-Esteem }\end{array}$ & $\begin{array}{c}0,695 * * \\
(0,000)\end{array}$ & $\begin{array}{c}0,511 * * \\
(0,000)\end{array}$ & $\begin{array}{c}0,432 * * \\
(0.000)\end{array}$ & 1,000 & $\begin{array}{c}0,665 * * \\
(0,000)\end{array}$ \\
\hline $\begin{array}{l}\text { Coopersmith } \\
\text { Self-Esteem } \\
\text { Inventory }\end{array}$ & $\begin{array}{c}0,844 * * \\
(0,000)\end{array}$ & $\begin{array}{c}0,760 * * \\
(0,000)\end{array}$ & $\begin{array}{c}0,691 * * \\
(0,000)\end{array}$ & $\begin{array}{c}0,665^{* *} \\
(0,000)\end{array}$ & 1,000 \\
\hline
\end{tabular}

* The correlation is significant at the 0.01 level.

Looking at the table, there is a statistically significant positive strong relationship between all subscales at $99 \%$ confidence level. Total scores a student obtained from subscales have the same directional relationship. As one increases, the other increases, or as one decreases the other decreases. In addition, there is a positive and very strong relationship between all subscales and 
the general scale. As the subscale total scores of the students increase or decrease, the overall scale total scores also increase or decrease.

\section{ANALYSIS OF TOTAL SCORES OF THE “COOPERSMITH SELF-ESTEEM INVENTORY” ACCORDING TO THE DEMOGRAPHIC PROPERTIES OF STUDENTS}

In the tables below, summary statistics based on demographic characteristics of the scale total scores, p-values obtained from the "Mann Whitney U" and "Kruskal Wallis 1 Way ANOVA" tests are given. The mean and standard deviation of each subscale are given according to the related grouped variable. In addition, in cases where there is a significant difference, the scales of the differences were determined by using the "Dunn's Nonparametric Comparison" test.

Table 13. The Results of the Coopersmith Self-Esteem and Sub-Inventory of High School Students Doing Sports towards Disabled Students by Age

\begin{tabular}{|c|c|c|c|c|c|c|c|c|c|}
\hline & \multicolumn{8}{|c|}{ Age } & \multirow{3}{*}{$\begin{array}{c}\text { p- } \\
\text { value } \\
\text { Sig.( }\end{array}$} \\
\hline & \multicolumn{2}{|c|}{15} & \multicolumn{2}{|c|}{16} & \multicolumn{2}{|c|}{17} & \multicolumn{2}{|c|}{18} & \\
\hline & Mea & SD & Mea & SD & Mean & SD & Mean & SD & \\
\hline General self- & 19,28 & 3,364 & 18,84 & 3,979 & 19,28 & 3,2932 & 19,171 & 3,3837 & 0,985 \\
\hline Social & 6,033 & 1,846 & 6,112 & 2,029 & 6,037 & 1,8219 & 6,2525 & 1,8089 & 0,829 \\
\hline Home-family & 4,736 & 2,827 & 4,887 & 2,713 & 4,700 & 2,9435 & 5,0404 & 2,7327 & 0,900 \\
\hline School- & 6,175 & 1,338 & 6,009 & 1,469 & 6,121 & 1,3082 & 6,1313 & 1,2506 & 0,934 \\
\hline $\begin{array}{l}\text { Coopersmith } \\
\text { self-esteem } \\
\text { inventory }\end{array}$ & $\begin{array}{c}36,23 \\
08\end{array}$ & $\begin{array}{c}8,069 \\
2\end{array}$ & $\begin{array}{c}35,85 \\
05\end{array}$ & $\begin{array}{c}8,844 \\
3\end{array}$ & $\begin{array}{c}36,14 \\
02\end{array}$ & 8,0287 & $\begin{array}{c}36,596 \\
0\end{array}$ & 7,7524 & 0,977 \\
\hline
\end{tabular}

Individuals' total scores from the "Coopersmith self-esteem inventory" and its subscales do not differ according to age ( $p>.05)$.

Table 14. The Results of the Coopersmith Self-Esteem and Sub-Inventory of High School Students Doing Sports towards Disabled Students by Gender

\begin{tabular}{|c|c|c|c|c|c|}
\hline & \multicolumn{4}{|c|}{ Gender } & \multirow{3}{*}{$\begin{array}{l}\text { p-value } \\
\text { (Sig.) }\end{array}$} \\
\hline & \multicolumn{2}{|c|}{ Male } & \multicolumn{2}{|c|}{ Female } & \\
\hline & Mean & SD & Mean & SD & \\
\hline $\begin{array}{l}\text { General self- } \\
\text { esteem }\end{array}$ & $\begin{array}{c}19,109 \\
7\end{array}$ & 3,5088 & $\begin{array}{c}19,247 \\
1\end{array}$ & 3,5620 & 0,795 \\
\hline $\begin{array}{l}\text { Social self- } \\
\text { esteem }\end{array}$ & 7,0752 & 1,8583 & 5,2353 & 1,9496 & $0,028^{*}$ \\
\hline $\begin{array}{l}\text { Home-family } \\
\text { self-esteem }\end{array}$ & 4,1649 & 2,8291 & 5,7294 & 2,6805 & $0,030^{*}$ \\
\hline $\begin{array}{l}\text { School- } \\
\text { academic self- } \\
\text { esteem }\end{array}$ & 5,1129 & 1,3387 & 7,0824 & 1,3646 & $0,029 *$ \\
\hline $\begin{array}{l}\text { Coopersmith } \\
\text { self-esteem } \\
\text { inventory }\end{array}$ & $\begin{array}{c}35,462 \\
7\end{array}$ & 8,2161 & $\begin{array}{c}37,294 \\
2\end{array}$ & 8,0252 & 0,761 \\
\hline
\end{tabular}

Individuals" "general self-esteem" levels and "Coopersmith self-esteem inventory" total scores do not differ according to gender $(\mathrm{p}>.05)$. However, men's "social self-esteem" levels were higher than women, while women's "home-family self-esteem" and "school-academic selfesteem" levels were higher than men $(p<.05)$. 
Table 15. The Results of the Coopersmith Self-Esteem and Sub-Inventory of High School Students Doing Sports towards Disabled Students by Mother's Education Level

\begin{tabular}{|c|c|c|c|c|c|c|c|c|c|}
\hline & \multicolumn{8}{|c|}{ Mother's Education Level } & \multirow{3}{*}{$\begin{array}{c}\text { p- } \\
\text { value } \\
\text { Sig. }\end{array}$} \\
\hline & \multicolumn{2}{|c|}{ Primary } & \multicolumn{2}{|c|}{ High School } & \multicolumn{2}{|c|}{ Undergraduat } & \multicolumn{2}{|c|}{ Postgraduate } & \\
\hline & Mea & SD & Mea & SD & Mean & SD & Mean & SD & \\
\hline Gener & 19,03 & 4,072 & 19,31 & 3,243 & & 6657 & 19,05 & & 0,964 \\
\hline Social & 6,974 & 1,814 & 6,627 & 1,884 & 6,037 & & 5,531 & & 0,001 \\
\hline Home-family & 5,133 & 2,648 & 4,754 & 2,819 & 4,897 & 2,8204 & 4,784 & $2, \varepsilon$ & 0,931 \\
\hline School- & 5,233 & 1,454 & 5,190 & 1,263 & 6,441 & 1,4136 & 6,658 & & 0,000 \\
\hline $\begin{array}{l}\text { Coopersmith } \\
\text { self-esteem } \\
\text { inventory }\end{array}$ & $\begin{array}{c}36,37 \\
39\end{array}$ & $\begin{array}{c}8,247 \\
6\end{array}$ & $\begin{array}{c}35,88 \\
90\end{array}$ & $\begin{array}{c}8,035 \\
8\end{array}$ & $\begin{array}{c}36,43 \\
70\end{array}$ & 8,2174 & $\begin{array}{c}36,03 \\
33\end{array}$ & 3453 & 0,944 \\
\hline
\end{tabular}

Individuals' levels of "general self-esteem", "home-family self-esteem" and "coopersmith selfesteem inventory" do not differ according to the education level of their mothers ( $p>.05)$. It is observed that individuals' 'social self-esteem' levels decrease as the education level of their mothers increases. In addition, the "school-academic self-esteem" levels of the individuals were found to be higher in individuals whose mother's education level was undergraduate or graduate compared to individuals with primary or high school education $(\mathrm{p}<.05)$.

Table 16. The Results of the Coopersmith Self-Esteem and Sub-Inventory of High School Students Doing Sports towards Disabled Students by Father's Education Level

\begin{tabular}{|c|c|c|c|c|c|c|c|}
\hline & \multicolumn{6}{|c|}{ Father's Education Level } & \multirow[b]{3}{*}{$\begin{array}{l}\text { p- } \\
\text { value } \\
\text { Sig. }\end{array}$} \\
\hline & \multicolumn{2}{|c|}{ High School } & \multicolumn{2}{|c|}{ Undergraduate } & \multicolumn{2}{|c|}{ Postgraduate } & \\
\hline & Mean & $\begin{array}{l}\text { Std. } \\
\text { Devia } \\
\text { tion }\end{array}$ & Mean & $\begin{array}{l}\text { Std. } \\
\text { Devia } \\
\text { tion }\end{array}$ & Mean & $\begin{array}{l}\text { Std. } \\
\text { Devia } \\
\text { tion }\end{array}$ & \\
\hline $\begin{array}{l}\text { General self- } \\
\text { esteem }\end{array}$ & $\begin{array}{c}19,210 \\
0\end{array}$ & 3,5570 & $\begin{array}{c}18,990 \\
8\end{array}$ & 3,6413 & $\begin{array}{c}19,425 \\
3\end{array}$ & 3,1498 & 0,690 \\
\hline $\begin{array}{l}\text { Social self- } \\
\text { esteem }\end{array}$ & 6,0300 & 1,9093 & 6,1429 & 1,8616 & 6,1149 & 1,8950 & 0,868 \\
\hline $\begin{array}{l}\text { Home-family } \\
\text { self-esteem }\end{array}$ & 4,7500 & 2,8652 & 4,8065 & 2,7937 & 5,0345 & 2,7595 & 0,871 \\
\hline $\begin{array}{l}\text { School- } \\
\text { academic self- } \\
\text { esteem }\end{array}$ & 6,1700 & 1,3031 & 6,1382 & 1,3503 & 5,9540 & 1,3717 & 0,483 \\
\hline $\begin{array}{l}\text { Coopersmith } \\
\text { self-esteem } \\
\text { inventory }\end{array}$ & $\begin{array}{c}36,160 \\
0\end{array}$ & 8,4300 & $\begin{array}{c}36,078 \\
3\end{array}$ & 8,2275 & $\begin{array}{c}36,528 \\
7\end{array}$ & 7,8010 & 0,861 \\
\hline
\end{tabular}

"Coopersmith self-esteem inventory" and subscale total scores of individuals do not differ statistically according to their fathers' educational status $(p>.05)$. 
Table 17. The Results of the Coopersmith Self-Esteem and Sub-Inventory of High School Students Doing Sports towards Disabled Students by Number of Siblings

\begin{tabular}{|c|c|c|c|c|c|c|c|}
\hline & \multicolumn{6}{|c|}{ Number of siblings } & \multirow{3}{*}{$\begin{array}{c}\text { p-value } \\
\text { (Sig.) }\end{array}$} \\
\hline & \multicolumn{2}{|c|}{1} & \multicolumn{2}{|c|}{2} & \multicolumn{2}{|c|}{3 and above } & \\
\hline & Mean & SD & Mean & SD & Mean & SD & \\
\hline General self-esteem & $\begin{array}{c}19,166 \\
7\end{array}$ & 3,2581 & $\begin{array}{c}19,362 \\
8\end{array}$ & 3,2220 & $\begin{array}{c}18,551 \\
7\end{array}$ & 4,3768 & 0,646 \\
\hline Social self-esteem & 6,0098 & 1,8747 & 6,1907 & 1,8127 & 6,0230 & 2,0401 & 0,673 \\
\hline $\begin{array}{l}\text { Home-family self- } \\
\text { esteem }\end{array}$ & 4,4059 & 2,8652 & 4,8605 & 2,8017 & 5,2540 & 2,7403 & $0,048^{*}$ \\
\hline $\begin{array}{l}\text { School-academic self- } \\
\text { esteem }\end{array}$ & 6,0784 & 1,2561 & 6,1070 & 1,3264 & 6,1379 & 1,4877 & 0,722 \\
\hline $\begin{array}{l}\text { Coopersmith self- } \\
\text { esteem inventory }\end{array}$ & $\begin{array}{c}35,660 \\
8 \\
\end{array}$ & 8,0048 & $\begin{array}{c}36,521 \\
0\end{array}$ & 7,8685 & $\begin{array}{c}35,966 \\
6\end{array}$ & 9,1049 & 0,698 \\
\hline
\end{tabular}

Individuals with 3 or more siblings have higher "home-family self-esteem" levels than individuals with fewer siblings $(p<.05)$. All other subscales and "Coopersmith self-esteem inventory" do not differ according to the number of siblings of individuals $(\mathrm{p}>.05)$.

Table 18. The Results of the Coopersmith Self-Esteem and Sub-Inventory of High School Students Doing Sports towards Disabled Students by Income Status

Income status

\begin{tabular}{|c|c|c|c|c|c|c|c|c|c|}
\hline & \multicolumn{2}{|c|}{$\begin{array}{c}2001-4000 \\
\text { TL }\end{array}$} & \multicolumn{2}{|c|}{$\begin{array}{c}4001-5000 \\
\text { TL }\end{array}$} & \multicolumn{2}{|c|}{$\begin{array}{c}5001-6000 \\
\text { TL }\end{array}$} & \multicolumn{2}{|c|}{$\begin{array}{c}6001 \mathrm{TL} \text { and } \\
\text { above }\end{array}$} & \multirow{2}{*}{$\begin{array}{l}\text { p- } \\
\text { value } \\
\text { Sig.( }\end{array}$} \\
\hline & $\begin{array}{c}\text { Mea } \\
\text { n }\end{array}$ & SD & $\begin{array}{c}\text { Mea } \\
\text { n }\end{array}$ & SD & Mean & SD & Mean & SD & \\
\hline $\begin{array}{l}\text { General self- } \\
\text { esteem }\end{array}$ & $\begin{array}{c}20,75 \\
00\end{array}$ & $\begin{array}{c}3,774 \\
9\end{array}$ & $\begin{array}{c}18,77 \\
91\end{array}$ & $\begin{array}{c}3,746 \\
0\end{array}$ & $\begin{array}{c}19,14 \\
86\end{array}$ & $\begin{array}{c}3,856 \\
7\end{array}$ & $\begin{array}{c}19,30 \\
22\end{array}$ & $\begin{array}{c}2,865 \\
7\end{array}$ & 0,752 \\
\hline $\begin{array}{l}\text { Social self- } \\
\text { esteem }\end{array}$ & $\begin{array}{c}7,750 \\
0\end{array}$ & $\begin{array}{c}0,500 \\
0\end{array}$ & $\begin{array}{c}6,104 \\
7\end{array}$ & $\begin{array}{c}1,795 \\
6\end{array}$ & $\begin{array}{c}6,182 \\
9\end{array}$ & $\begin{array}{c}1,903 \\
0\end{array}$ & $\begin{array}{c}5,971 \\
2\end{array}$ & $\begin{array}{c}1,903 \\
2\end{array}$ & $\begin{array}{c}0,007 \\
*\end{array}$ \\
\hline $\begin{array}{l}\text { Home-family } \\
\text { self-esteem }\end{array}$ & $\begin{array}{c}7,250 \\
0\end{array}$ & $\begin{array}{c}0,957 \\
4\end{array}$ & $\begin{array}{c}4,534 \\
9\end{array}$ & $\begin{array}{c}2,864 \\
3\end{array}$ & $\begin{array}{c}5,108 \\
6\end{array}$ & $\begin{array}{c}2,702 \\
6\end{array}$ & $\begin{array}{c}4,625 \\
9\end{array}$ & $\begin{array}{c}2,869 \\
8\end{array}$ & $\begin{array}{l}0,000 \\
*\end{array}$ \\
\hline $\begin{array}{l}\text { School- } \\
\text { academic self- } \\
\text { esteem }\end{array}$ & 6,000 & $\begin{array}{c}2,449 \\
4\end{array}$ & $\begin{array}{c}5,872 \\
1\end{array}$ & $\begin{array}{l}1,516 \\
9\end{array}$ & $\begin{array}{c}6,182 \\
9\end{array}$ & $\begin{array}{c}1,326 \\
4\end{array}$ & $\begin{array}{c}6,158 \\
3\end{array}$ & $\begin{array}{c}1,205 \\
4\end{array}$ & 0,360 \\
\hline $\begin{array}{l}\text { Coopersmith } \\
\text { self-esteem } \\
\text { inventory }\end{array}$ & $\begin{array}{c}41,75 \\
00\end{array}$ & $\begin{array}{c}7,135 \\
5\end{array}$ & $\begin{array}{c}35,29 \\
07\end{array}$ & $\begin{array}{c}8,372 \\
0\end{array}$ & $\begin{array}{c}36,62 \\
29\end{array}$ & $\begin{array}{c}8,481 \\
5\end{array}$ & $\begin{array}{c}36,05 \\
76\end{array}$ & $\begin{array}{c}7,636 \\
4\end{array}$ & $\begin{array}{l}0,000 \\
*\end{array}$ \\
\hline
\end{tabular}

Individuals" "general self-esteem" and "school-academic self-esteem" levels do not differ according to their income levels ( $p>.05)$. However, the total scores of "social self-esteem", "home-family self-esteem" and "Coopersmith self-esteem inventory" were higher in individuals with an income of 2001 - 4000 TL compared to individuals with higher income ( $p$ <.05). 
Table 19. The Results of the Coopersmith Self-Esteem and Sub-Inventory of High School Students Doing Sports towards Disabled Students by Sport Branch

\begin{tabular}{|c|c|c|c|c|c|}
\hline & \multicolumn{4}{|c|}{ Sport Branch } & \multirow{3}{*}{$\begin{array}{l}\text { p-value } \\
\text { (Sig.) }\end{array}$} \\
\hline & \multicolumn{2}{|c|}{ Individual Sports } & \multicolumn{2}{|c|}{ Team sports } & \\
\hline & Mean & SD & Mean & SD & \\
\hline $\begin{array}{l}\text { General self- } \\
\text { esteem }\end{array}$ & $\begin{array}{c}19,744 \\
8\end{array}$ & 3,2979 & $\begin{array}{c}18,580 \\
5\end{array}$ & 3,6349 & 0,786 \\
\hline $\begin{array}{l}\text { Social self- } \\
\text { esteem }\end{array}$ & 6,7378 & 1,7879 & 5,5383 & 1,9231 & $0,000^{*}$ \\
\hline $\begin{array}{l}\text { Home-family } \\
\text { self-esteem }\end{array}$ & 5,4161 & 2,7488 & 4,3008 & 2,8309 & $0,001 *$ \\
\hline $\begin{array}{l}\text { School- } \\
\text { academic self- } \\
\text { esteem }\end{array}$ & 6,6888 & 1,2215 & 5,5613 & 1,4046 & $0,001 *$ \\
\hline $\begin{array}{l}\text { Coopersmith } \\
\text { self-esteem } \\
\text { inventory }\end{array}$ & $\begin{array}{c}38,587 \\
5\end{array}$ & 7,7553 & $\begin{array}{c}33,980 \\
9\end{array}$ & 8,3961 & $0,000 *$ \\
\hline
\end{tabular}

Individuals" "general self-esteem" levels do not differ according to sports branches ( $p>.05$ ). However, individuals dealing with individual sports have higher levels of "coopersmith selfesteem inventory", "social self-esteem", "home-family self-esteem" and "school-academic selfesteem" than individuals engaged in team sports $(p<.05)$.

Table 20. Kendall's Tau-B Correlation Coefficient of the Relationship between the Total Scores of the High School Students Doing Sports in Social Acceptance Scale towards Disabled Students and the "Coopersmith Self-Esteem Inventory"

\begin{tabular}{ccc}
\cline { 2 - 2 } & $\begin{array}{c}\text { Social } \\
\text { Acceptance } \\
\text { Scale }\end{array}$ & $\begin{array}{c}\text { Coopersmith } \\
\text { Self-Esteem } \\
\text { Inventory }\end{array}$ \\
\hline $\begin{array}{c}\text { Social } \\
\text { Acceptance } \\
\text { Scale }\end{array}$ & 1,000 & 0,069 \\
$\begin{array}{c}\text { Coopersmith } \\
\text { Self-Esteem } \\
\text { Inventory }\end{array}$ & 0,069 & $1,077)$ \\
\hline \multirow{2}{*}{ The correlation is significant at the 0.01 level. }
\end{tabular}

When looking at the table, there is no statistically significant relationship between the total scores of the "social acceptance scale" and the "Coopersmith self-esteem inventory" $(p>.05)$ and the answers given to these scales and the total scores obtained are independent from each other.

\section{Discussion and Conclusion}

Within the scope of the research, it was aimed to examine the relationship between social acceptance and self-esteem levels of high school students doing sports towards disabled students.

There is no statistically significant difference between the total score averages of the social acceptance and subscale of the students according to their ages $(p>.05)$. In this study, it was found that age does not affect the social acceptance level. In the studies of Rosenthal et al. (2006) and Tervo and Palmer (2004), there are studies that found that age does not affect the attitude towards disabled people. We can say that students at any age have positive social acceptance or attitudes towards disabled students.

Students' "Social skills" and "peer attitude" levels do not differ by gender ( $p>.05)$. However, "student behavior" subscale total scores and "social acceptance scale" are higher in men than in women ( $\mathrm{p}<.05)$. In the studies of İscan et al (2014); Kargın and Baydık (2002), Karataş and Arslan (2018), it is stated that gender does not affect the disability attitude. In other 
studies, Sarı et al. (2010); Sucuoğlu and Kargın (2006) found that there is a significant difference between the scores of attitudes towards disabled people and the average score of girls is higher than boys. We can say that the reason why female students' social acceptance or attitudes towards disabled people is higher than that of men is that they have equal opportunities thanks to their changing lifestyles and they can do sports freely and show themselves and are emotional. In the work we have done, we can mention that the reason why men have higher scored than women about social acceptance is that few women participated in the study.

Excluding the students' "social skills" subscale mean score $(\mathrm{p}<.05)$ no significant difference was found in the other subscales and social acceptance scale total mean scores ( $p>$ .05 ). It is seen that as the graduation degrees of the mothers and fathers of the students increase, the social skill levels of their children decrease inversely.

Individuals" "student behaviors" and "peer attitude" subscale total scores do not differ according to the education level of their mothers ( $p>.05)$. However, the total scores of the "social skills" subscale and the "social acceptance scale" of individuals whose mother's education level is post graduate is lower than that of individuals whose mother's education level is primary, high school, and undergraduate $(\mathrm{p}<.05)$. The finding that there is no significant difference about social acceptance according to education level of mother is seen in the studies of Dolanay (2016), Aydoğan (2017), Ayral et al. (2015), Arslan and Karataş (2018). There are also studies in the literature that have different results. Pettit et al. (2009); Şentürk (2007) found that the education level of the mother is effective in the social acceptance of her children. In our study, it was concluded that the level of education was not effective.

Students' total scores they got from the "social acceptance scale" and its subscales do not differ according to their fathers' educational status ( $p>.05)$. It is seen that there is no significant difference about social acceptance in terms of the education level of father in the stuies of Dolanay (2016), Aydoğan (2017), Ayral et al. (2015), Arslan and Karataş (2018). They found that fathers' education levels were not effective in their children's social acceptance. In other words, we can say that the education level is not effective on the social acceptance levels of the child.

There is no statistically significant difference between the subscales of the students according to the number of siblings and the social acceptance scale total score averages ( $\mathrm{p}>.05)$. In similar studies (Karataş \& Arslan, 2018; Ayral et al., 2013; Erdemir, 2015; Güngören, (2011); Sungur, (2010); Dağlı et al. (2017), Ayral et al. (2015) concluded that there is no relationship between the number of siblings and the level of social acceptance. Since the number of siblings is not effective on social acceptance, it is concluded that there is no relationship between social acceptance level and number of siblings. We can say that students' point of view to disabled students is not related to the number of siblings.

Students "peer attitude" subscale total score averages do not differ according to their families' income ( $p>.05)$. Mean scores of "social skills", "student behavior" subscale and social acceptance scale differ significantly $(\mathrm{p}<.05)$. Individuals" "social skills" and "student behavior" subscale total scores and "social acceptance scale" total scores were found to be lower in individuals with an income of s2001 - 4000 TL compared to individuals with higher income. In the studies it is seen that social acceptance differs according to socio-economic level and social acceptance, social skills and student behaviors increase as the socioeconomic level increases. In the studies conducted, it was concluded that the social acceptance of the students did not differ significantly according to the income level of the family. Similar studies also found that children with good socio-economic status develop a more positive attitude towards social acceptance (Parasuram, 2006; Robinson, Martin, \& Thompson, 2007; Ayral et al, 2013; Ayral et al., 2015; Aydoğan, 2017). We can say that social acceptance has an effect on income.

The total scores obtained by individuals from "social skills", "student behavior" and "peer attitude" subscales do not differ according to sport branches $(\mathrm{p}>.05)$. However, the total scores of "social acceptance scale" of individuals dealing with individual sports were higher than those dealing with "team sports" $(\mathrm{p}<.05)$. In the findings of our study, a significant difference was found between the social acceptance levels of the students who participated in individual and team sports activities. There is no significant difference in other subscales. The reason why the 
students who do individual sports are higher than team sports is that the social acceptance of the students who do individual sports is alone in sports, because they face everything alone. Social anxiety levels of students who do sports are lower. Regardless of the branch of sports the student is engaged in, we can say that sports are effective on social acceptance. No findings were obtained to support our study. Sports are extremely effective for individuals to communicate with other individuals in a healthy way and to reach self-confidence. Due to this situation, social acceptance is higher in individuals who do individual sports. An individual who does sports does not discriminate people. Every individual knows that he/she is valuable. He/she helps people regardless of their disability and knows that people with disabilities are part of a society.

The students' total score averages from the Coopersmith self-esteem inventory and its subscales do not differ according to their age ( $p>.05)$. In this study, it was found that age did not affect self-esteem. In the study conducted by Ünlü (2015), Y1lmaz and Ekinci (2001), it was concluded that there was no relationship between age and self-esteem. We can say that different age groups are not effective on self-esteem.

Students' "general self-esteem" levels and "Coopersmith self-esteem inventory" total scores do not differ by gender ( $\mathrm{p}>$.05). However, men's "social self-esteem" levels were higher than women, while women's "home-family self-esteem" and "school-academic self-esteem" levels were higher than men $(\mathrm{p}<.05)$. When looking at the studies conducted by Avşaroğlu (2007); Emil (2003); Suner (2000), it is seen that male and female students had similar self-esteem levels. In the subscales, we can say that some items are effective on gender. We can say that men are more social because their "social self-esteem" levels are higher than women as women stay in the background and men come to the forefront due to social differences. On the other hand, women have higher levels of "home-family self-esteem" and "school-academic self-esteem" than men because women give more importance to family structure than men, and the place of women at home is different and important, and high school-academic self-esteem is the result of women's success and attitude at school and. In addition, women's doing sports increased awareness. It has brought confidence in themselves. Male and female students have a high level of self-esteem due to regular exercise. There are differences in some items. Students' perspectives change because sports affect students' self-esteem, empathy and emotional intelligence. In short, sport is effective on emotion and thought.

Students' levels of "general self-esteem", "home-family self-esteem" and "Coopersmith self-esteem inventory" do not differ according to the education level of their mothers ( $p>.05)$. It is observed that individuals" "social self-esteem" levels decrease as the education level of their mothers increases. In addition, the "school-academic self-esteem" levels of the individuals were found to be higher in individuals whose mother's education level was undergraduate or post graduate compared to individuals with primary or high school education $(p<.05)$. In some of the results of the research examining the effects of the mother's educational status on self-esteem, it was found that as the mother's education level increases, her child's self-esteem increases (Ayval1, 2012; Çetin, 2015; Erbil et al.2006; Aktaş; Honey, 2005; Aydoğan, 2010).

Students" "Coopersmith self-esteem inventory" and subscale total scores do not differ statistically according to the education level of their fathers $(\mathrm{p}>.05)$. In the results of the study done, it has been found that there is no significant difference between education level and selfesteem and its subscales in the results of the study examining the self-esteem and subscales of the father's education (Dilek, 2007; Ceylan, 2013; Sarıkaya, 2015). We can say that the father's education level has no effect on self-esteem and its subscales.

Individuals with three or more siblings have higher "home-family self-esteem" levels than individuals with fewer siblings $(\mathrm{p}<.05)$. All other subscales and "Coopersmith self-esteem inventory" do not differ according to the number of siblings of individuals $(p>.05)$. In the study conducted by Ceylan, (2013); Yücel, (2013); Çetin, (2015); Y1lmaz et al. (2012), it is stated that the number of siblings does not make a significant difference on self-esteem. We can say that the number of siblings does not affect self-esteem. We can state that the reason why individuals with three or more siblings have higher "home-family self-esteem" levels than individuals with fewer siblings is due to the higher number of siblings. As the number of siblings increases, it affects the feelings and thoughts of siblings towards each other. As the number of siblings increases, it encourages sharing and being tolerant and respectful to each other. 
Individuals' "general self-esteem" and "school-academic self-esteem" levels do not differ according to their income levels $(\mathrm{p}>.05)$. However, the total scores of "social self-esteem", "home-family self-esteem" and "Coopersmith self-esteem inventory" were higher in individuals with an income of 2001 - 4000 TL compared to individuals with higher income ( $\mathrm{p}<.05)$. The studies of Asic1 (2013), Kahriman (2002), Balat and Akman (2004) reveal that self-esteem does not differ according to income level. We can say that some items are effective in income level on self-esteem, and some items are not.

Students" "general self-esteem" levels do not differ according to sports branches ( $p>.05)$. However, individuals dealing with individual sports have higher levels of "coopersmith selfesteem inventory", "social self-esteem", "home-family self-esteem" and "school-academic selfesteem" than individuals dealing with team sports $(p<.05)$.

Self-esteem is higher in team sports than individual sports. We can say that the reason for this is that the athletes in team sports have a higher level of self-esteem compared to individual sports because they appear as a team in sports matches and fight together with an opponent. There is a team spirit in team sports. They fight in the team as a whole. They are never desperate, they are combative and support each other and close the gap. We can say that the general self-esteem levels among the subscales do not differ according to sports branches, because both of them have high general self-esteem levels. In the study of Dalbudak \& Yiğit (2019); Aktop \& Erman (2002), no significant difference was found between team sports and individual sports athletes' selfesteem levels. Sport contributes to self-esteem positively on the individuals who are engaged in individual and team sports. Since sports affects individuals' emotions and thoughts positively, we can mention that they live more in peace with themselves and look at life more positively.

According to the statistical results, there is no statistically significant relationship between the total "social acceptance scale" and the "coopersmith self-esteem inventory" and the answers given to these scales and the total scores are independent from each other ( $p>.05)$. Accordingly, there is no relationship between social acceptance level and self-esteem (self). They do not affect each other. We cannot say that individuals with high self-esteem have high social acceptance. No findings were obtained to support our study.

Considering these results, it can be said that the importance of sport is great because it is effective in students' lives. Since sport affects not only body but also emotions and thoughts, it adds difference to students' perspective towards individuals in society. Students who do sports are sensitive to people with disabilities. They know they are part of society. All of this is due to the influence of sport on personality. Sport enables them to live in peace with all individuals in the society and to look at life more positively.

\section{References}

1. Aktaş, S. (2011) 9. Investigation of the Relationship Between Parental Attitudes and SelfEsteem in the Classroom in Terms of Some Variables . Master Thesis, Selcuk University Institute of Educational Sciences, Konya.

2. Aktaş, C., \& Küçüker, S. (2002). Investigation of the Effect of a Cognitive-Affective Focused Program on the Social Acceptance Levels of Primary School Students for Their Physically Handicapped Peers. Ankara University Faculty of Educational Sciences Special Education Journal, 3, 15-25.

3. Aktop, A., \& Erman, KA (2002). Comparison of Achievement Motivation, Self Anxiety and Trait Anxiety Levels of Team and Individual Athletes . 7. International Sport Sciences Congress, Antalya.

4. Arslan, E. (2010). A Scale Development Study for Determining the Social Acceptance Levels of Students with Disabilities Participating in Inclusive Practices . Master Thesis, Mehmet Akif Ersoy University Institute of Social Sciences, Burdur.

5. As1c1, E. (2013). An Investigation of Teacher Candidates' Forgiveness Characteristics in Terms of Self-Awareness and Self-Esteem . Yüksek Lisans Tezi, Dokuz Eylül Üniversitesi, Eğitim Bilimleri Enstitüsü, İzmir. 
6. Avşaroğlu, S. (2007). Investigation of University Students' Self-Esteem in Decision Making, Decision Making and Coping with Stress in terms of Self-Esteem and Some Variables, Selçuk University, Journal of Social Sciences Institute, Konya. P.18, P. 85-100.

7. Aydoğan, C. (2017). Social Acceptance of Individuals in Different Life Periods Regarding Mentally Handicapped Individuals, Master Thesis, Yıldırım Beyazit University, Institute of Health Sciences, Ankara.

8. Aydoğan, S. (2010). Primary Education II. Investigation of Level Students' Hope and SelfEsteem Levels in Terms of Some Variables . Master's Thesis. Selçuk University Institute of Social Sciences, Konya.

9. Ayral, M., Özcan, Ş., Can, R., Ünlü, A., Bedel, H., Şengün, G., Demirhan, Ş., \& Çağlar, K. (2013). Social Acceptance Levels of Inclusion Students, ELMIS International Special Education Congress, Akșehir, Konya.

10. Ayral, M., Şaydan, Ö., Can, R., Ünlü A., Bedel, H., Şengün, G., Demirhan, Ş., \& Çağlar, K. (2015). Factors Affecting the Perspective of Normally Developing Students on Special Needs Students . Abant İzel Baysal University Journal of Education Faculty, 15, 218-230.

11. Ayval1, M. (2012). Primary Education 4. and 5. The Relationship Between Class Students' Self-Esteem and Social Adaptation. Master Thesis, Nineteen May University, Samsun.

12. Balat, G. \& Akman, B. (2004). Investigation of Self-Esteem Levels of High School Students at Different Socio-Economic Levels. Firat University Journal of Social Sciences, 14 (2), 175-183.

13. Honey, EY (2005). The Effect of Exercising on Adolescents' Self-Esteem and SelfEfficacy. Master Thesis, Mersin University, Mersin.

14. Buhs, ES, \& Ladd, GW (2001). Peer rejection as antecedent of young children's school adjustment: An examination of mediating processes. Developmental Psychology, 37 (4), 550.

15. Ceylan, İ. (2013). An Investigation of Adolescents' Self-Esteem and Emotional SelfEfficacy. Master Thesis, Dokuz Eylül University, İzmir

16. Cohen, AR (1959). Some implications of self-esteem for social influence. In IL Janies et al. (Eds.), Personality and persuasibility (pp. 102-120). New Haven, [Conn.]: Yale University Press.

17. Coopersmith, S. (1974). The antecedents of self-esteem. WH Freeman and company San Francisco.

18. Çetin, B. (2015). Investigation of Self-Esteem and Aggression Levels of Adult Middle School Students in Urban and Rural Areas. Master Thesis, Nişantaşı University, Istanbul.

19. Dalbudak, İ., \& Yiğit Ş.M. (2019). Investigation of Self Levels of Hearing Impaired Individuals Who Do Sports and Do Not Do Sports. Turkish Studies Social Sciences Volume 14 Issue 4, p. 1387-1398.

20. Dewall, CN, \& Bushman, BJ (2011)."Social acceptance and rejection: the sweet and the bitter", Current Directions in Psychological Science, S. 20, p. 256--260.

21. Doğan, İ. (2018). Educational sociology. Nobel Publication.

22. Dolanay, D. (2016). The Relationship Between Acceptance of Special Needs Children of Mothers and Admission of Siblings With Special Needs Children. Master's Thesis. Near East University Institute of Educational Sciences, Special Education Department, TRNC.

23. Dilek, H. (2007). High School Continuing Different Education Programs 1. Investigation of the Relationship between Classroom Students 'Self-Esteem and Parents' Self-Esteem. Master Thesis, Gazi University, Ankara.

24. Emil, S. (2003). Self-esteem and stressful life events of university students (Unpublished master thesis). Middle East Technical University, Graduate School of Social Sciences, Ankara.

25. Erbil, N., Divan, Z., \& Önder, P. (2006). The Effect of Families 'Attitudes and Behaviors on Adolescents' Self-Esteem. Journal of Social Policy Studies, 10 (10), 7- 15.

26. Erdemir, Y. (2015). A Comparison of Children With or Without Depression in Terms of Social Adaptation. Master Thesis, Beykent University, Istanbul. 
27. Güçray, S. (1989) "Some Factors Affecting Self-Esteem of 9-10-11 Years Old Children Staying in Kindergarten and with Their Families", Unpublished PhD Thesis, Hacettepe University, Ankara.

28. Güngören, D. (2011). The Effects of Marriage Conflict on Social Adaptation and Skills of 5-6 Years Old Children Attending Preschool Education Institution. Master's Thesis. Maltepe Üniversitesi, İstanbul.

29. İşcan, G., Fazlıoğlu, Y., \& Parlak, C. (2014).Investigation of Attitudes of Normally Developing Children Attending Primary School towards Their Disabled Peers, Abant İzzet Baysal University Faculty of Education Journal, 15: 128-138.

30. Kahriman, İ. (2002). The Relationship between Perceived Social Support from Family and Friends and Self-Esteem in Adolescents. Master's Thesis. Atatürk Üniversitesi Sağlık Bilimleri Enstitüsü. Erzulum.

31. Karataş, Z., \& Arslan, E., (2018). Examination of social acceptance of inclusion students with mental retardation in secondary school by their peers with normal development. Mehmet Akif Ersoy University Journal of Education Faculty , 48, 495-513.

32. Kargın, T., \& Baydık, B. (2002). Investigation of the Attitudes of Hearing Students in the Inclusion Environment towards Their Hearing-Impaired Peers in terms of Various Variables, Ankara University Faculty of Educational Sciences Special Education Journal, 2002, 3 (2): 27-39.

33. Kuzgun, Y. (2000). Vocational Counseling. Ankara: Nobel Yayın Dağıtım

34. Mağden, D., \& Küçük Aksoy, A. (1993). Investigation of the Relationship between Locus of Control and Self-Esteem. 9. Preschool Education and Dissemination Seminar. Ankara: Ya-pa Publications.

35. Öcal, D. (1999). A review on the communication and inclusion of mentally retarded children with other children. Master's Thesis. Ankara University Institute of Social Sciences.

36. Özyürek, M. (2006). Changing attitudes towards the disabled. Ankara: Kök Yayıncılık.

37. Parasuram, K. (2006). Variables That effect teachers' attitudes toward disability and inclusive education in Mumbai, India. Disability and Society, 21 (3), 232-242.

38. Pettit, GS, Yu, T., Dodge, KA, \& Bates, JE (2009). A development process analysis of cross-generational continuity in educational attainment. Merril-Palmer Quarterly , 55 (3), 250-284.

39. Pişkin, M. (1996). Self-Esteem, Locus of Control and Academic Achievement of Secondary School Children both in England and Turkey. PhD Thesis. University of Leicester, Faculty of Education and Continuing Studies. UK

40. Pişkin, M. (2000). Self-esteem development training (Edt. Yıldız Kuzgun), guidance in primary education. Nobel Yayın Dağıtım, Ankara.

41. Robinson, C., Martin, J., \& Thompson, K. (2007). Attitudes towards and perceptions of disabled people - findings from a module included in the 2005 British Social Attitudes Survey. Disability Rights Commission.

42. Rosenberg, M. (1965). Society and the adolescent self-image. Princeton University Press, USA, New Jersey.

43. Rosenthal, DA, Chan, F., \& Livenh, H. (2006). Rehabilitation students' attitudes toward persons with disabilities in high- and low-stakes social contexts: A conjoint analysis. Disabil Rehabil, 28: 1517-1527.

44. Sarkaya, A. (2015). The Relationship Between Self-Esteem and Psychological Resilience Levels of Adolescents Between 14-18 Years. Master Thesis, Istanbul Bilim University, Istanbul.

45. Sarı, YH, Bektaş M., \& Altıparmak, S. (2010). Determination of nursing students' attitudes towards disabled people, New Medical Journal, 80-83.

46. Selimoğlu, H., \& Aydan, A. (2019). The effect of peer teaching on social acceptance and self-esteem of individuals with intellectual disabilities. Hacettepe University Journal of Education, 34 (3), 639-658.

47. Sucuoğlu, B., \& Kargın, T. (2006). Integration Practices, Approaches, Methods, Techniques, in Primary Education. İstanbul: Morpa Kültür Yayınları. 
48. Sungur, G. (2010). Investigation of Social Adaptation and Skills of Primary School First Grade Children. Master's Thesis. Selcuk University, Konya

49. Suner, E. (2000). The Relationship Between Self-Esteem, Academic Achievement and Trait Anxiety Levels of Adolescents in Different High Schools. Yayınlanmamış Yüksek Lisans Tezi. İzmir: Dokuz Eylül Publications.

50. Şentürk, S. (2007). Comparison of the Child Rearing Attitudes of Working and NonWorking Mothers of 5-6 Year Old Children with Their Social-Emotional Adaptation Levels . Master Thesis, Istanbul: Marmara University, Institute of Educational Sciences,

51. Tervo, RC ,. \& Palmer, G. (2004). Health professional student attitudes towards people with disability. Clin Rehabil, 18: 908-915.

52. Ünlü, F. (2015). Investigation of the Relationship Between Self-Esteem, Loneliness and Attachment Styles in Divorced Parents. Master Thesis, Haliç University, Istanbul.

53. Yiğit, R., \& Y1lmaz, H. (2011). Primary Education II. Investigation of the Relationship Between Level Students' Social Skills Levels and Self-Esteem. Selcuk University Ahmet Keleşoğlu Faculty of Education Journal, 31,335- 347

54. Y1lmaz, S., \& Ekinci, M. (2001). The Relationship Between Self-Esteem and Assertiveness Level in Nursing School Students. Journal of Anatolia Nursing and Health Sciences, 4 (2), 1-10.

55. Yücel, Y. (2013). The Relationship Between Secondary School Students Perceived Parental Attitudes, Self-Esteem and Learned Helplessness. Master Thesis, Arel University, Istanbul. 